\title{
PROFESSOR INGRID ULRIKA OLSSON (1927-2018): IN MEMORIAM
}

Göran Possnert ${ }^{1 *(1)} \cdot$ Farid El-Daoushy ${ }^{2}$

${ }^{1}$ Tandem Laboratory, Uppsala University, Box 529, SE-751 20, Uppsala, Sweden

${ }^{2}$ Department of Physics and Astronomy, Uppsala University, Box 516, SE-751 20, Uppsala, Sweden

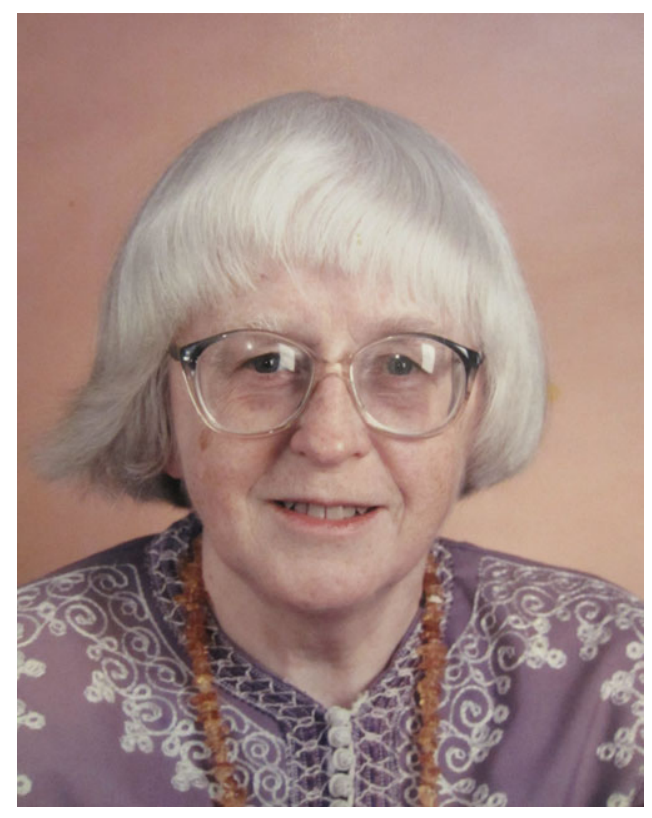

Ingrid Ulrika Olsson

1927-2018

Ingrid Ulrika Olsson started her $\mathrm{PhD}$ studies early in the 1950s working in semi-conductor physics. After only one year she had to change fields when Professor Kai Siegbahn (1981 Nobel Prize laureate) became the new department head. He wanted to set up a modern radiocarbon laboratory in Uppsala and in contrast to the tricky and ineffective solid carbon technique used in the already established laboratory in Stockholm, he wanted to measure radiocarbon with gas proportional counters. Ingrid was therefore sent to Groningen for five months to learn the technique by professor H. de Vries.

Returning to Uppsala, Ingrid successfully built a laboratory after solving several instrumental challenges related to low-level counting using passive "iron" and active shielding with "GMtubes." In 1962 she defended her PhD thesis, "A Study of Some Problems Connected with C ${ }^{14}$ Dating." Besides instrumental development, sample handling, burning and purification of the carbon dioxide from electronegative impurities before being introduced to the detectors and diverse applications in Quaternary geology and archaeology (including Egyptology), the absolute determination of the radiocarbon half-life was presented. 
With almost 65 years of research in radiocarbon, Ingrid had addressed several of the main questions. She summarized her contributions in a quite comprehensive Radiocarbon article (Olsson 2009).

She was critical and always concerned about improving the accuracies and reliability in chronological studies by careful attention to the origin of samples and errors related to sources of contamination, e.g., reservoir effect. Sample pre-treatments were adapted
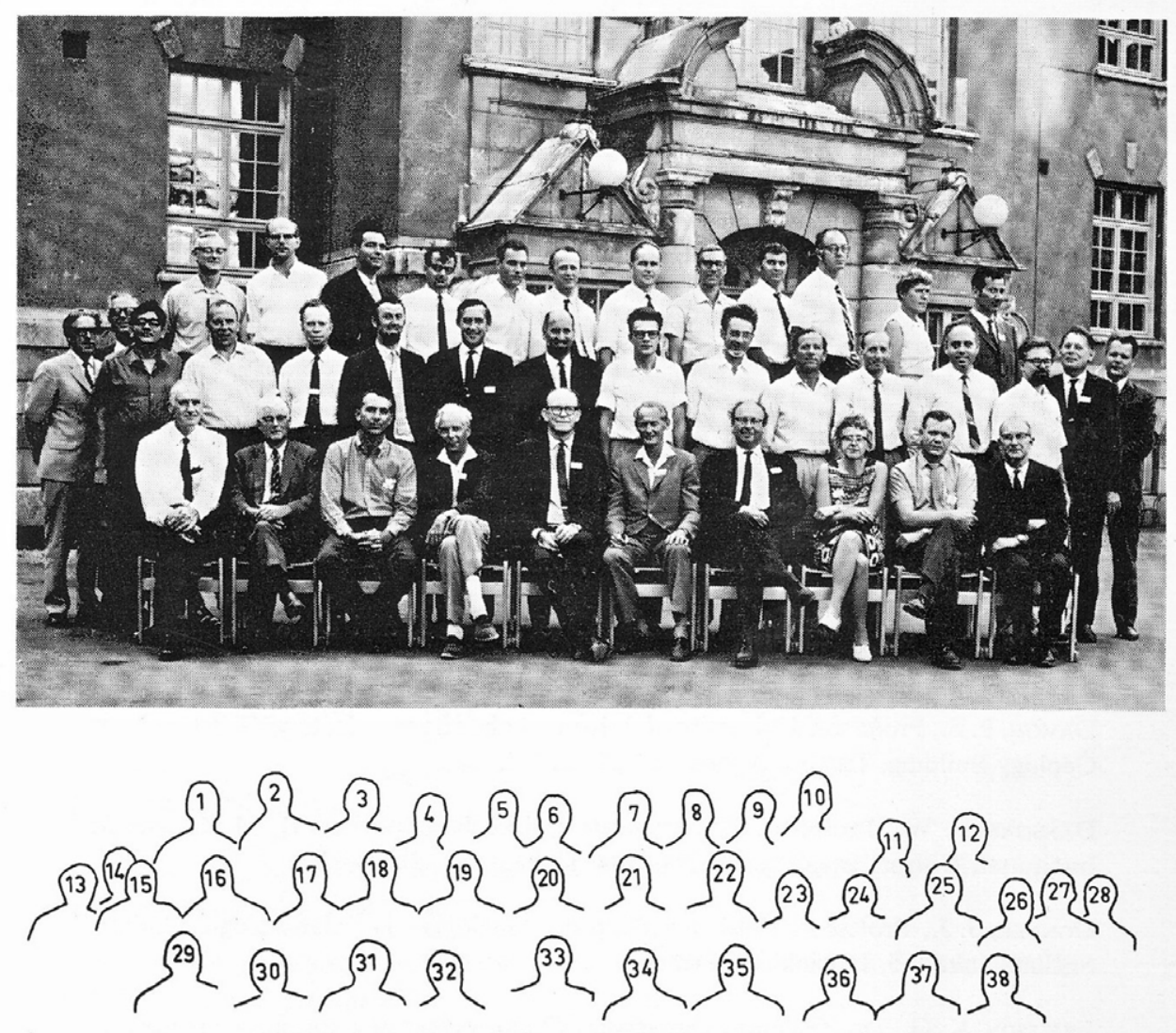

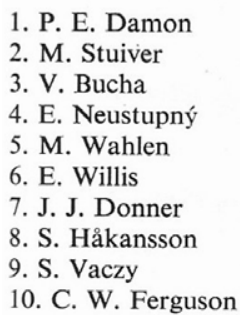

1. P. E. Damon
2. M. Stuiver
3. V. Bucha
4. E. Neustupný
5. M. Wahlen
6. E. Willis
7. J. J. Donner
8. S. Håkansson
9. S. Vaczy
10. C. W. Ferguson

21. J. C. Lerman
22. W. Dansgaard
23. M. J. Aitken
24. H. Tauber
25. R. Ramaty
26. D. L. Thurber
27. H. N. Michael
28. K. G. Eriksson
29. R. F. Flint
30. F. Johnson

31. F. Wendorf

32. T. Säve-Söderbergh

33. W. F. Libby

34. K. Siegbahn

35. H. E. Suess

36. I. U. Olsson

37. J. C. Vogel

38. T. A. Rafter

(Photograph: Aros Foto)

Participants at the 12th Nobel Symposium in Uppsala 1969 devoted to Radiocarbon Variability and Absolute Chronology. 
depending on origin and composition (archaeological artifacts, bone remains, peat-deposits, aquatic shells, and sediments). In addition, uncertainties in low-level $\beta$-counting, e.g., detector calibration and performance, background, and memory-effects were carefully considered.

Ingrid was especially interested in radiocarbon applications in the polar region with a focus on Iceland (impact of volcanic activity) and Spitzbergen (being considered "clean air").

In 1969 Ingrid organized the 12th Nobel Symposium in Uppsala devoted to Radiocarbon Variability and Absolute Chronology. The symposium represented a summary of the first 20 years of radiocarbon research, and the main topics discussed at that time are still the same today. The radiocarbon community was still relatively small in 1969 and almost all key persons in the field were gathered at the meeting (including W. Libby, 1960 Nobel Prize laureate in Chemistry). Already at that time, ${ }^{14} \mathrm{C}$ provided means to assess the role of natural versus anthropogenic carbon on the climate.

Ingrid became a corresponding member of the Royal Swedish Academy of Letters, History and Antiquities in 1979. She was not only interested in radiocarbon but also one of the initiators of successful activities using U/Th-isotopes, e.g., the ${ }^{210} \mathrm{~Pb}$-method, and the AMS in Uppsala (1977).

Besides her time in the laboratory, she loved to go to her summer house close to Uppsala where she relaxed from work but also collected submerged plants and other samples for her scientific projects. Cross-country skiing and Swedish folk dancing were other activities of interest to her as well as writing poetry.

\section{REFERENCE}

Olsson IU. 2009. Radiocarbon dating history: early days, questions, and problems met.

Radiocarbon 51(1):1-43. doi: 10.1017/S00338 22200033695 . 